\title{
PENGARUH MODEL POGIL, GAYA KOGNITIF, DAN MOTIVASI BERPRESTASI TERHADAP PEMAHAMAN KONSEP IPA SISWA KELAS V SD
}

\author{
I Kd. Dwi Sarjana, I Gd. Margunayasa \\ Jurusan Pendidikan Guru Sekolah Dasar, Fakultas Ilmu Pendidikan \\ Universitas Pendidikan Ganesha, Jln. Udayana No. 11 Singaraja \\ e-mail: dwisarjana99@gmail.com
}

\begin{abstract}
The study was aimed to analyze the effect of Process Oriented Guided Inquiry Learning (POGIL), cognitive styles, and achievement motivation toward science concept understanding. The research using non-equivalent post-test only control group design. The population of this research is all of the fifth grade student in elementary school belonging to the Group I of Negara district in academic years 2015/2016. The sample was taken out of two classes using random sampling technique. The collected data were analyzed by two-way Analysis of covarians with one covariable and product moment. The result of the research showed that (1) there are significant differences of science concept understanding between the group of students who studied with POGIL models and the group of students who learned with conventional models after controlling achievement motivation $(F=9,590$, with Sig. $=$ $0,003<0,05)$, (2) there are significant differences of science concept understanding between the group of students who have impulsive cognitive style and the group of students who have reflective cognitive style after controlling achievement motivation $(\mathrm{F}=10,529$, with Sig. $=$ $0,002<0,05),(3)$ there are not significant interaction between learning models and cognitive styles toward science concept understanding after controlling achievement motivation $(\mathrm{F}=$ $0,517$, with Sig. $=0,476>0,05)$, and (4) there are significant correlation of student achievement motivation with science concept understanding on fifth grade student in elementary school belonging to the Group I of Negara district in academic years 2015/2016. (Sig. $=0,000<0,05)$.
\end{abstract}

Keywords: POGIL models, cognitive styles, science concept understanding, achievement motivation

\begin{abstract}
ABSTRAK: Penelitian ini bertujuan untuk mengetahui pengaruh model POGIL, gaya kognitif, dan motivasi berprestasi terhadap pemahaman konsep IPA. Rancangan penelitian yang digunakan adalah non-equivalent post-test only control group design. Populasi dalam penelitian ini yaitu siswa kelas V SD di Gugus I Kecamatan Negara tahun pelajaran 2015/2016. Sampel diambil dengan teknik random sampling. Data yang telah dikumpulkan, dianalisis dengan uji Anakova 2 jalur 1 kovariabel dan korelasi product moment. Hasil penelitian menunjukkan bahwa (1) terdapat perbedaan yang signifikan dalam pemahaman konsep IPA antara kelompok siswa yang dibelajarkan dengan model POGIL dan kelompok siswa yang dibelajarkan dengan pembelajaran konvensional setelah mengontrol motivasi berprestasi $(F=9,590$, dengan Sig. $=0,003<0,05)$, (2) terdapat perbedaan yang signifikan dalam pemahaman konsep IPA antara kelompok siswa yang memiliki gaya kognitif impulsif dan kelompok siswa yang memiliki gaya kognitif reflektif setelah mengontrol motivasi berprestasi $(\mathrm{F}=10,529$, dengan Sig. $=0,002<0,05)$, (3) tidak terdapat interaksi yang signifikan antara model pembelajaran dan gaya kognitif dalam pengaruhnya terhadap pemahaman konsep IPA setelah mengontrol motivasi berprestasi $(\mathrm{F}=0,517$, dengan Sig. $=$ $0,476>0,05)$, dan (4) terdapat korelasi yang signifikan antara motivasi berprestasi dengan pemahaman konsep IPA pada siswa kelas V SD di Gugus I Kecamatan Negara Tahun Pelajaran 2015/2016 (Sig. $=0,000<0,05)$.
\end{abstract}

Kata-kata kunci: model POGIL, gaya kognitif, pemahaman konsep IPA, motivasi berprestasi 
Pendidikan nasional berfungsi untuk mengembangkan dan membentuk watak serta peradaban bangsa yang bermartabat dalam rangka mencerdaskan kehidupan bangsa, dengan tujuan dapat berkembangnya potensi peserta didik agar menjadi manusia yang beriman dan bertaqwa kepada Tuhan Yang Maha Esa, berakhlak mulia, sehat, berilmu, cakap, kreatif, mandiri, dan menjadi warga negara yang demokratis serta bertanggung jawab (UU No. 20 Tahun 2003, pasal 3). Dengan demikian, diharapkan semua warga negara Indonesia menjadi manusia yang berkualitas dan proaktif menjawab tantangan global sesuai dengan tujuan pendidikan nasional. Untuk mencapai warga negara Indonesia yang berkualitas dan proaktif menjawab tantangan global, ada banyak hal yang dapat dilakukan, salah satunya adalah melalui peningkatan kualitas pembelajaran IPA.

Untuk meningkatkan kualitas pembelajaran IPA, maka pemahaman konsep terhadap objek IPA mutlak diperlukan. Teori konstruktivisme memandang bahwa untuk dapat memahami konsep IPA, maka keaktifan siswa untuk membangun pengetahuannya sendiri sangat diperlukan. Suatu konsep disusun berdasarkan konsep-konsep sebelumnya, dan akan menjadi dasar bagi konsep-konsep selanjutnya, sehingga pemahaman yang salah terhadap suatu konsep, akan berakibat pada kesalahan pemahaman terhadap konsep-konsep selanjutnya.

Dalam rangka peningkatan pemahaman konsep IPA siswa, maka seorang tenaga pendidik perlu melakukan upaya yang inovatif dalam pembelajaran yang membuat siswa tertarik untuk belajar IPA. Salah satu model pembelajaran yang sesuai dengan hal tersebut adalah model POGIL (Process Oriented Guided Inquiry Learning). Model POGIL dikembangkan berdasarkan paham konstruktivisme. Hale dan Mullen (2009) menyatakan bahwa tujuan dari rancangan pengajaran (POGIL) ini adalah (1) untuk mengembangkan penguasan konten/isi; dan (2) untuk mengembangkan keterampilan prosesorientasi seperti pemecahan masalah, berpikir kritis dan analitis, dan komunikasi lisan dan tulisan. Kegiatan model POGIL dibangun di atas kerangka siklus pembelajaran (learning cycle), sebuah pendekatan yang terbukti efektif dalam pembelajaran IPA (Karplus et al., dalam Simonson dan Shadle, 2013). Barthlow (2011) menyatakan bahwa siklus pembelajaran (learning cycle) terdiri atas tiga tahap, yaitu eksplorasi (exploration), penemuan konsep (concept invention), dan aplikasi (application). Eksplorasi dimaksudkan untuk menggali konsepsi awal siswa. Pengenalan atau penemuan konsep adalah tahap guru mengumpulkan informasi dari para siswa berkaitan dengan pengalaman mereka dalam tahap eksplorasi, sedangkan penerapan atau aplikasi adalah tahap guru menyiapkan situasi yang dapat dipecahkan berdasarkan pengalaman eksplorasi dan pengenalan konsep-konsep. Pada tahap ini diberikan permasalahan yang dapat dipecahkan dengan menerapkan konsep-konsep yang telah dijelaskan sebelumnya.

Selain proses pembelajaran dengan menerapkan model pembelajaran inovatif, guru juga harus memperhatikan berbagai macam karakteristik yang dimiliki siswa, salah satunya adalah gaya kognitif. Gaya kognitif adalah, "Cara seseorang dalam memproses, menyimpan, maupun menggunakan informasi untuk menanggapi suatu tugas atau menanggapi berbagai jenis situasi lingkungannya" (Daraini, 2012). Berdasarkan waktu yang digunakan untuk merespon suatu stimulus, gaya kognitif dibagi menjadi dua, yaitu gaya kognitif impulsif dan gaya kognitif reflektif. Kagan et al., (dalam Backhaus dan Liff, 2007) mengemukakan bahwa pebelajar yang memiliki gaya kognitif reflektif memiliki karakteristik mempertimbangkan sesuatu hal dengan detail sebelum mengambil keputusan. Sedangkan pebelajar yang memiliki gaya kognitif impulsif memiliki karakteristik mencapai keputusan dengan cepat tanpa memerlukan suatu pertimbangan yang hati-hati. Sebagai seorang guru haruslah mengerti akan adanya keterkaitan antara pemahaman konsep yang dihasilkan dari masing-masing gaya kognitif tersebut.

Selain gaya kognitif, yang patut menjadi bahan pertimbangan guru dalam melaksanakan pembelajaran adalah motivasi berprestasi. Halawah dan Johnson et al., (dalam Muldrow, 2008) menyatakan, "Achievement motivation is defined as one's commitment to the learning process." Artinya bahwa motivasi berprestasi didefinisikan sebagai komitmen seseorang pada proses pembelajaran. Siswa yang memiliki komitmen tinggi dalam proses pembelajaran akan meningkatkan usahanya pada tugas yang sulit, gigih saat menghadapi rintangan, dan cenderung menentukan tujuan yang menantang. 
Implikasinya pada pemahaman konsep IPA adalah jika motivasi berprestasi siswa tinggi, maka mereka akan cenderung lebih mudah dalam memahami konsep IPA. Begitu pula sebaliknya, jika motivasi berprestasi siswa rendah, maka mereka akan cenderung lebih sulit dalam memahami konsep IPA.

Berdasarkan hasil observasi yang dilakukan pada Jumat, 15 Januari 2016 pada siswa kelas $\mathrm{V}$ ditemukan bahwa rata-rata siswa pada saat belajar masih kurang aktif. Ini disebabkan karena guru masih dominan menggunakan metode ceramah. Metode tersebut kurang memberikan kesempatan kepada siswa untuk lebih aktif, baik secara fisik maupun secara psikologis. Hal ini akan berdampak pada rendahnya pemahaman siswa terhadap konsep IPA. Beberapa faktor yang menjadi penyebab rendahnya pemahaman siswa terhadap konsep IPA yaitu pertama, guru sangat jarang menggunakan media pembelajaran dalam menyampaikan konsep IPA yang akan diajarkan. Guru hanya terpaku pada penggunaan spidol dan papan tulis untuk menyampaikan konsep IPA yang akan diajarkan. Hal ini akan membuat penanaman konsep kepada siswa dimulai dari hal yang abstrak. Dalam hal ini, penanaman konsep seharusnya dimulai dari hal yang konkret menuju hal yang abstrak. Kedua, penyampaian guru dalam pembelajaran IPA hanya menggunakan metode ceramah. Banyak guru yang beranggapan bahwa metode ceramah merupakan metode pembelajaran yang paling praktis, mudah, dan efisien. Guru beranggapan bahwa siswa telah menguasai meteri sama halnya dengan apa yang telah guru kuasai. Padahal siswa merasa kesulitan dalam memahami konsep dalam pembelajaran IPA.

Berdasarkan wawancara yang dilakukan terhadap beberapa orang siswa yang memiliki nilai IPA di bawah rata-rata diketahui bahwa motivasi dan minat mereka untuk belajar IPA rendah. Mereka menganggap bahwa (1) IPA itu cukup sulit, (2) penjelasan guru kurang bisa dipahami, dan (3) pembelajaran kurang menarik. Jika ditanya tentang mata pelajaran yang disukai, mereka menjawab IPS, PKn, Penjas dan SBK. Atas dasar ini, peneliti merasa perlu untuk mengimplementasikan model POGIL ditinjau dari gaya kognitif dan melihat pengaruhnya terhadap pemahaman konsep IPA setelah mengontrol motivasi berprestasi pada Siswa Kelas V SD di Gugus I Kecamatan Negara Tahun Pelajaran 2015/2016.
Tujuan penelitian ini adalah (1) menganalisis perbedaan pemahaman konsep IPA antara kelompok siswa yang dibelajarkan dengan model POGIL dan kelompok siswa yang dibelajarkan dengan model pembelajaran konvensional setelah mengontrol motivasi berprestasi, (2) menganalisis perbedaan pemahaman konsep IPA antara kelompok siswa yang memiliki gaya kognitif impulsif dan kelompok siswa yang memiliki gaya kognitif reflektif setelah mengontrol motivasi berprestasi, (3) menganalisis interaksi antara model pembelajaran dan gaya kognitif dalam pengaruhnya terhadap pemahaman konsep IPA setelah mengontrol motivasi berprestasi, dan (4) menganalisis korelasi antara motivasi berprestasi dengan pemahaman konsep IPA pada siswa kelas V SD di Gugus I Kecamatan Negara Tahun Pelajaran 2015/2016.

\section{METODE}

Penelitian ini merupakan penelitian kuasi eksperimen yang dilaksanakan di Gugus I, Kecamatan Negara dengan jumlah populasi 192 siswa, yang terdiri atas 96 siswa laki-laki dan 96 siswa perempuan. Penelitian ini menggunakan rancangan non equivalent post-test only control group design. Berdasarkan karakteristik populasi dan tidak bisa dilakukannya pengacakan individu, maka pengambilan sampel pada penelitian ini dilakukan dengan teknik group random sampling. Sebelum menentukan sampel penelitian, populasi tersebut diuji kesetaraannya berdasarkan nilai UAS IPA semester ganjil dengan uji Anava 1 jalur. Berdasarkan hasil uji kesetaraan yang dilakukan dengan program SPSS 16.0 for windows, diketahui bahwa kemampuan siswa di gugus tersebut telah setara.

Setelah dilakukan uji kesetaraan, selanjutnya sampel dalam penelitian ini ditetapkan 2 kelas yang setara yaitu kelas V SD Negeri 3 Banjar Tengah yang berjumlah 39 orang siswa sebagai kelompok eksperimen dan kelas V SD Negeri 2 Banjar Tengah yang berjumlah 40 orang siswa sebagai kelompok kontrol. Variabel dalam penelitian ini terdiri atas variabel independent, yakni model pembelajaran, variabel dependent, yakni pemahaman konsep IPA, variabel moderator yakni gaya kognitif, dan kovariabel yakni motivasi berprestasi. 
Tabel 1. Deskripsi Nilai Pemahaman Konsep IPA

\begin{tabular}{crrrrrrr}
\hline Kelompok & $\begin{array}{r}\text { Rata- } \\
\text { rata }\end{array}$ & Median & Modus & $\begin{array}{r}\text { Standar } \\
\text { Deviasi }\end{array}$ & Varians & $\begin{array}{r}\text { Nilai } \\
\text { Minimum }\end{array}$ & $\begin{array}{r}\text { Nilai } \\
\text { Maksimum }\end{array}$ \\
\hline $\mathrm{A}_{1}$ & 79,03 & 83,33 & 90 & 10,83 & 117,37 & 50 & 90 \\
\hline $\mathrm{A}_{2}$ & 68,61 & 71,66 & 63,33 & 12,16 & 147,77 & 40 & 86,67 \\
\hline $\mathrm{B}_{1}$ & 67,36 & 68,33 & 63,33 & 12,78 & 163,27 & 40 & 90 \\
\hline $\mathrm{B}_{2}$ & 80,28 & 81,66 & 76,67 & 8,45 & 71,43 & 63,33 & 90 \\
\hline $\mathrm{A}_{1} \mathrm{~B}_{1}$ & 73,06 & 71,66 & 66,67 & 11,41 & 130,21 & 50 & 90 \\
\hline $\mathrm{A}_{1} \mathrm{~B}_{2}$ & 85,00 & 86,67 & 86,67 & 6,11 & 37,37 & 70 & 90 \\
\hline $\mathrm{A}_{2} \mathrm{~B}_{1}$ & 61,67 & 61,66 & 53,33 & 11,85 & 140,41 & 40 & 80 \\
\hline $\mathrm{A}_{2} \mathrm{~B}_{2}$ & 75,56 & 76,67 & 76,67 & 7,96 & 63,33 & 63,33 & 86,67 \\
\hline
\end{tabular}

Keterangan:

$\mathrm{A}_{1}=$ Model POGIL

$\mathrm{A}_{2}=$ Model Pembelajaran Konvensional

$\mathrm{B}_{1}=$ Gaya Kognitif Impulsif

$\mathrm{B}_{2}=$ Gaya Kognitif Reflektif

Metode pengumpulan data yang digunakan adalah metode tes dan kuesioner. Tes yang digunakan terdiri atas tes pemahaman konsep IPA dan Matching Familiar Figure Test (MFFT), sedangkan kuesioner yang digunakan adalah kuesioner motivasi berprestasi. Data yang dikumpulkan dianalisis menggunakan analisis statistik deskriptif dan Anakova 2 jalur 1 kovariabel.

\section{HASIL DAN PEMBAHASAN}

\section{Hasil}

Berdasarkan analisis data yang dilakukan terhadap nilai pemahaman konsep IPA, diperoleh hasil seperti yang tersaji pada Tabel 1 . Berdasarkan Tabel 1, diketahui bahwa (1) ratarata nilai pemahaman konsep IPA pada siswa yang dibelajarkan dengan model POGIL adalah 79,028 dengan kategori sangat tinggi. Sedangkan rata-rata nilai pemahaman konsep IPA pada siswa yang dibelajarkan dengan pembelajaran konvensional sebesar 68,611 dengan kategori tinggi. Secara deskriptif, dapat dijelaskan bahwa kelompok siswa yang dibelajarkan dengan model POGIL memiliki tingkat pemahaman konsep IPA yang lebih baik dibandingkan dengan kelompok siswa yang dibelajarkan dengan pembelajaran konvensional; (2) rata-rata nilai pemahaman konsep IPA pada siswa yang memiliki gaya kognitif impulsif adalah 67,361 dengan kategori tinggi, sedangkan rata-rata nilai pemahaman konsep IPA pada siswa yang memiliki gaya kognitif reflektif adalah 80,28 dengan kategori sangat tinggi. Secara deskriptif, dapat dijelaskan bahwa kelompok siswa yang memiliki gaya kognitif reflektif memiliki tingkat pemahaman konsep IPA yang lebih baik dibandingkan dengan kelompok siswa yang memiliki gaya kognitif impulsif; (3) pada siswa yang dibelajarkan dengan model POGIL, ratarata nilai pemahaman konsep IPA pada siswa impulsif sebesar 73,06, sedangkan rata-rata nilai pemahaman konsep IPA pada siswa reflektif sebesar 85,001. Pada siswa yang dibelajarkan dengan pembelajaran konvensional, rata-rata nilai pemahaman konsep IPA pada siswa impulsif sebesar 61,67, sedangkan rata-rata nilai pemahaman konsep IPA pada siswa reflektif sebesar 75,56. Hal ini mengindikasikan bahwa model POGIL lebih unggul daripada model pembelajaran konvensional untuk pencapaian pemahaman konsep IPA pada siswa impulsif dan siswa reflektif.

Sebelum dilakukan pengujian hipotesis, terlebih dahulu dilakukan uji prasyarat yaitu uji normalitas, uji homogenitas, dan uji linearitas. Berdasarkan hasil pengujian prasyarat diperoleh bahwa data pemahaman konsep IPA berdistribusi normal, varians kedua kelompok homogen, dan regresi linear. Setelah semua asumsi terpenuhi, selanjutnya dilakukan pengujian hipotesis ke-1, ke-2, dan ke-3 dengan uji Anakova 2 jalur 1 kovariabel. Sedangkan hipotesis ke-4 diuji dengan korelasi product 
moment. Hasil pengujian hipotesis dengan uji Anakova tersaji pada Tabel 2.

Berdasarkan Tabel 2, diketahui bahwa (1) nilai $F$ untuk sumber data antar model pembelajaran sebesar 9,590 dengan signifikansi sebesar 0,003 (Sig. < 0,05). Ini berarti $\mathrm{H}_{0}$ ditolak, atau $\mathrm{H}_{1}$ diterima. Dengan kata lain dapat disimpulkan bahwa terdapat perbedaan yang signifikan pemahaman konsep IPA antara kelompok siswa yang dibelajarkan dengan model POGIL dan kelompok siswa yang dibelajarkan dengan model pembelajaran konvensional setelah mengontrol motivasi berprestasi; (2) nilai $\mathrm{F}$ untuk sumber data antar gaya kognitif sebesar 10,529, dengan moment sebesar 0,641 dengan signifikansi sebesar 0,000 (Sig. < 0,05). Hal ini menunjukkan bahwa $\mathrm{H}_{0}$ ditolak, atau $\mathrm{H}_{1}$ diterima. Dengan demikian, dapat disimpulkan bahwa terdapat korelasi yang signifikan motivasi berprestasi dengan pemahaman konsep IPA.

\section{Pembahasan}

Berdasarkan hasil pengujian dengan Anakova 2 jalur 1 kovariabel dan dengan analisis korelasi product moment, diketahui bahwa dari keempat hipotesis yang diajukan, hanya 1 hipotesis yang tidak diterima, yaitu

Tabel 2. Hasil Uji Anakova 2 Jalur 1 Kovariabel (Uji Hipotesis ke-1, ke-2, dan ke-3)

\begin{tabular}{crrrrrrr}
\hline Sumber & $\begin{array}{r}\text { Jumlah } \\
\text { kuadrat }\end{array}$ & db & $\begin{array}{r}\text { Rata-rata } \\
\text { Kuadrat }\end{array}$ & F & Sig. & Keterangan \\
\hline $\mathrm{X}$ & 1054,524 & 1 & 1054,524 & 14,965 & 0,000 & Signifikan \\
\hline $\mathrm{A}$ & 675,790 & 1 & 675,790 & 9,590 & 0,003 & Signifikan \\
\hline $\mathrm{B}$ & 741,955 & 1 & 741,955 & 10,529 & 0,002 & Signifikan \\
\hline A*B & 36,429 & 1 & 36,429 & 0,517 & 0,476 & Tidak signifikan \\
\hline dalam kelompok & 3030,078 & 43 & 70,467 & & & \\
\hline Total & 7400,585 & 47 & & & & \\
\hline
\end{tabular}

Keterangan:

$\mathrm{A} \quad=$ Model pembelajaran

$\mathrm{B}=$ Gaya kognitif

$\mathrm{A} * \mathrm{~B}=$ Interaksi antara model pembelajaran dan gaya kognitif

$\mathrm{X}=$ Motivasi berprestasi

signifikansi sebesar 0,002 (Sig. < 0,05). Hal ini berarti $\mathrm{H}_{0}$ ditolak, atau $\mathrm{H}_{1}$ diterima. Dengan kata lain dapat disimpulkan bahwa terdapat perbedaan yang signifikan pemahaman konsep IPA antara kelompok siswa yang memiliki gaya kognitif impulsif dan kelompok siswa yang memiliki gaya kognitif reflektif setelah mengontrol motivasi berprestasi; (3) nilai $\mathrm{F}$ untuk sumber data interaksi antara model pembelajaran dan gaya kognitif sebesar 0,517, dengan signifikansi sebesar 0,476 (Sig. > 0,05). Hal ini berarti $\mathrm{H}_{0}$ diterima, atau $\mathrm{H}_{1}$ ditolak. Dengan kata lain, dapat disimpulkan bahwa tidak terjadi interaksi antara model pembelajaran dan gaya kognitif dalam pengaruhnya terhadap pemahaman konsep IPA setelah mengontrol motivasi berprestasi. Untuk pengujian hipotesis keempat dilakukan dengan uji korelasi product moment. Berdasarkan pengujian, diperoleh koefisien korelasi product hipotesis ketiga tentang interaksi antara model pembelajaran dan gaya kognitif terhadap pemahaman konsep IPA setelah mengontrol motivasi berprestasi. Berdasarkan pengujian yang dilakukan, diketahui bahwa (1) pemahaman konsep IPA pada siswa yang dibelajarkan dengan model POGIL lebih tinggi dibandingkan dengan pemahaman konsep IPA pada siswa yang dibelajarkan dengan pembelajaran konvensional; (2) pemahaman konsep IPA pada siswa yang memiliki gaya kognitif reflektif lebih tinggi dibandingkan dengan pemahaman konsep IPA pada siswa yang memiliki gaya kognitif impulsif; (3) tidak terdapat interaksi antara model pembelajaran dan gaya kognitif dalam pengaruhnya terhadap pemahaman konsep IPA; (4) teradapat korelasi yang signifikan antara motivasi berprestasi dengan pemahaman konsep IPA 


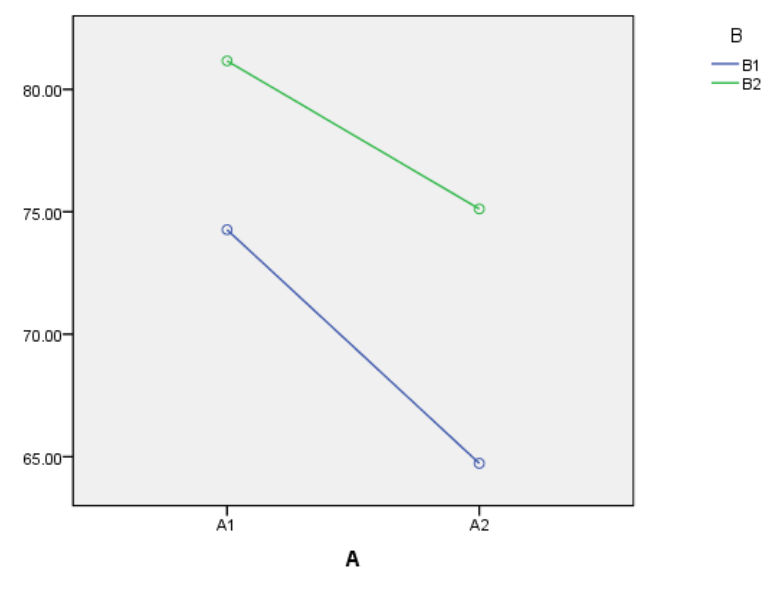

Gambar 1. Profil Interaksi antara Model
Pembelajaran dengan Gaya
Kognitif terhadap Pemahaman
Konsep IPA

Berdasarkan Gambar 1 diketahui bahwa interaksi yang terjadi merupakan interaksi ordinal (tidak bersilangan). Gambar 1 juga menjelaskan bahwa walaupun tidak terjadi interaksi antara model pembelajaran dan gaya kognitif terhadap pemahaman konsep IPA, tetapi peningkatan pemahaman konsep IPA pada siswa impulsif dan siswa reflektif yang dibelajarkan dengan model POGIL masih lebih tinggi dibandingkan dengan siswa yang dibelajarkan dengan pembelajaran konvensional. Dengan kata lain, model POGIL sesuai diterapkan dalam pembelajaran IPA untuk siswa yang bergaya kognitif impulsif maupun siswa yang bergaya kognitif reflektif.

Ketiadaan interaksi disebabkan oleh karakteristik siswa reflektif yang cenderung memberikan respon yang lambat karena melalui serangkaian analisis sehingga respon yang diberikan cenderung benar. Sehingga ketika siswa reflektif menghadapi suatu permasalahan baik dalam model POGIL ataupun pembelajaran konvensional, mereka akan menggunakan cara berpikir yang analitis untuk menyelesaikannya. Dengan demikian, pemahaman konsep IPA pada siswa reflektif akan cenderung lebih tinggi dibandingkan dengan pemahaman konsep IPA pada siswa impulsif yang dibelajarkan dengan model POGIL maupun pembelajaran konvensional. Walaupun demikian, model POGIL tetap memberikan implikasi yang positif terhadap siswa impulsif. Hal ini didasarkan pada rata-rata nilai pemahaman kosep IPA siswa yang memiliki gaya kognitif impulsif yang dibelajarkan dengan model POGIL lebih tinggi dibandingkan dengan rata-rata nilai pemahaman konsep IPA siswa impulsif yang dibelajarkan dengan model konvensional $\left(\mu \mathrm{A}_{1} \mathrm{~B}_{1}=73,06>\right.$ $\left.\mu \mathrm{A}_{2} \mathrm{~B}_{1}=61,67\right)$.

Keberhasilan peningkatan pemahaman konsep IPA pada siswa impulsif dan reflektif tidak lepas dari penerapan model POGIL. Kegiatan model POGIL dibangun di atas kerangka siklus pembelajaran, sebuah pendekatan yang terbukti efektif dalam pembelajaran IPA (Karplus et al., dalam Simonson dan Shadle, 2013). Siklus pembelajaran (learning cycle) terdiri atas tiga tahap, yaitu eksplorasi, penemuan konsep, dan aplikasi. Hanson (2006) mengemukakan bahwa dalam model ini, tahap-tahap pembelajaran yang harus dilalui oleh siswa adalah (1) siswa menerima sebuah masalah, (2) menyusun hipotesis, (3) siswa melakukan eksplorasi (mencari jawaban), (4) siswa memahami konsep, (5) siswa mulai mengaplikasikan pengetahuan yang dimiliki, (6) mengaplikasikan pengetahuan ke dalam konsep baru, dan (7) siswa memperoleh refleksi dan evaluasi dari guru. Tahapan-tahapan ini akan membawa siswa pada keterampilan pemrosesan informasi, berpikir kritis dan analitis, pemecahan masalah, komunikasi, kerjasama kelompok, manajemen, dan penilaian. Dengan kata lain, model POGIL menuntut kemandirian siswa, kerja tim, serta berpikir analitis untuk dapat memecahkan setiap persoalan yang dihadapi. Guru hanya berperan sebagai monitor, fasilitator, dan evaluator dalam pembelajaran (Barthlow dan Watson, 2011).

Berbeda halnya dengan pembelajaran konvensional yang berpusat pada guru. Peserta didik berperan sebagai pengikut dan penerima pasif dari kegiatan yang dilaksanakan. Sulaeman (dalam Rasana, 2009:18) menambahkan bahwa pembelajaran konvensional merupakan metode yang paling efisien dalam mengajar yang bersifat hafalan (ingatan). Dalam pembelajaran ini, guru tidak menghubungkan pengetahuan awal siswa dengan materi yang akan dipelajari. Siswa masih dianggap seperti "kertas kosong" yang masih perlu diisi pengetahuan oleh guru. Dengan demikian, kegiatan untuk mengarahkan siswa pada kemampuan berpikir kritis dan analitis jarang dilakukan. Akibatnya adalah kemampuan pemahaman konsep IPA siswa cenderung rendah.

Pada pembelajaran dengan model POGIL, siswa dibimbing untuk dapat menemukan konsep mereka sendiri. Guru hanya 
memfasilitasi apabila siswa menemui kesulitan dalam pembelajaran, dan guru akan mengonfirmasi konsep yang mereka temukan sehingga tidak terjadi miskonsepsi. Pembelajaran dengan model ini akan membawa siswa pada pemahaman konsep yang lebih baik dibandingkan dengan pembelajaran konvensional.

Hasil penelitian ini sejalan dengan hasil penelitian sebelumnya, seperti hasil penelitian Hale dan Mullen (2009), Simonson dan Shadle (2013), Barthlow dan Watson (2011), dan Sulastriningsih dan Suranata (2013) yang menunjukkan bahwa model POGIL cenderung lebih baik dibandingkan dengan model konvensional.

Penelitian ini menunjukkan bahwa keefektifan suatu model pembelajaran dalam meningkatkan pemahaman konsep IPA siswa berkaitan dengan salah satu faktor psikologis siswa, yakni gaya kognitif impulsif dan gaya kognitif reflektif. Hal ini berdampak pada 1) keefektifan suatu model pembelajaran dalam meningkatkan pemahaman konsep IPA dapat dibantu dengan mempertimbangkan gaya kognitif siswa; 2) model POGIL sangat sesuai untuk meningkatkan pemahaman konsep IPA bagi siswa reflektif. Karakteristik siswa reflektif yang menghabiskan lebih banyak waktu untuk memeriksa masalah, mempertimbangkan solusi alternatif, dan memeriksa kelengkapan hipotesis sehingga respon yang diberikan cenderung benar sangat sesuai dibelajarkan dengan model POGIL yang menuntut siswa untuk berpikir dan bekerja seperti ilmuwan; 3) melalui penerapan model POGIL, pemahaman konsep IPA pada siswa reflektif dan siswa impulsif dapat meningkat. Hal ini didasarkan pada hasil penelitian yang menunjukkan bahwa walaupun tidak terjadi interaksi antara model pembelajaran dan gaya kognitif terhadap pemahaman konsep IPA, tetapi secara deskriptif, profil interaksi mengindikasikan bahwa pemahaman konsep IPA pada siswa reflektif dan siswa impulsif yang dibelajarkan dengan model POGIL lebih tinggi dibandingkan dengan kelompok siswa yang dibelajarkan dengan pembelajaran konvensional.

Walaupun secara umum model POGIL dapat dikatakan sesuai diterapkan dalam pembelajaran IPA di SD, tetapi masih ada kendala-kendala yang dihadapi. Kendala tersebut antara lain: 1) sulitnya membagi kelompok belajar. Hal ini disebabkan oleh siswa cenderung ingin berkelompok dengan teman dekat mereka. Sehingga tidak jarang dalam setiap kelompok hanya terdiri atas siswa perempuan saja, atau siswa laki-laki saja. 2) beberapa siswa sering kali ribut saat pembelajaran berlangsung, dan membuat suasana pembelajaran kurang kondusif. Dalam menyelesaikan kedua permasalahan tersebut, disiasati dengan pembagian kelompok ditentukan oleh guru. Hal ini bertujuan agar kelompok yang terbentuk merupakan kelompok yang heterogen. Kelompok atau siswa yang membuat keributan akan diberikan sanksi berupa pengurangan skor untuk kelompoknya atau untuk siswa yang bersangkutan. Berdasarkan tindakan yang telah dilakukan, maka kendala-kendala tersebut dapat diatasi selama proses pembelajaran berlangsung dari pertemuan pertama sampai pertemuan kedelapan.

\section{SIMPULAN}

Hasil pengujian terhadap keempat hipotesis yang diajukan pada penelitian ini menghasilkan simpulan sebagai berikut. 1) terdapat perbedaan yang signifikan pemahaman konsep IPA antara kelompok siswa yang dibelajarkan dengan model POGIL dan kelompok siswa yang dibelajarkan dengan pembelajaran konvensional setelah mengontrol motivasi berprestasi $(\mathrm{F}=9,590$; Sig. $(0,003)<0,05)$. Hal ini ditunjukkan oleh rata-rata nilai pemahaman konsep IPA pada siswa yang dibelajarkan dengan model POGIL lebih besar dibandingkan dengan rata-rata nilai pemahaman konsep IPA pada siswa yang dibelajarkan dengan pembelajaran konvensional $(79,028>68,611)$; 2) terdapat perbedaan yang signifikan pemahaman konsep IPA antara kelompok siswa yang memiliki gaya kognitif impulsif dan kelompok siswa yang memiliki gaya kognitif reflektif setelah mengontrol motivasi berprestasi ( $\mathrm{F}=10,529$, Sig. $(0,002)<0,05)$. Hal ini ditunjukkan oleh rata-rata nilai pemahaman konsep IPA pada siswa yang memiliki gaya kognitif reflektif lebih besar dibandingkan dengan rata-rata nilai pemahaman konsep IPA pada siswa yang memiliki gaya kognitif impulsif $(80,28>$ 67,361); 3) tidak terdapat interaksi yang signifikan antara model pembelajaran dan gaya kognitif terhadap pemahaman konsep IPA setelah mengontrol motivasi berprestasi. 
Hal ini ditunjukkan oleh rata-rata nilai pemahaman konsep IPA pada siswa reflektif yang dibelajarkan dengan model POGIL lebih besar dibandingkan dengan rata-rata nilai pemahaman konsep IPA pada siswa reflektif yang dibelajarkan dengan pembelajaran konvensional $(85,001>75,56)$. Begitu pula dengan rata-rata nilai pemahaman konsep IPA pada siswa impulsif yang dibelajarkan dengan model POGIL lebih besar dibandingkan dengan rata-rata nilai pemahaman konsep IPA pada siswa impulsif yang dibelajarkan dengan pembelajaran konvensional $(73,06>61,67)$; dan 4) terdapat korelasi yang signifikan antara motivasi berprestasi dengan pemahaman konsep IPA. Hal ini ditunjukkan oleh koefisien korelasi product moment sebesar 0,641 dengan Sig. $(0,000)<0,05$.

Beberapa saran terkait dengan penelitian ini adalah sebagai berikut. 1) guru hendaknya menggunakan model POGIL sebagai salah satu alternatif model pembelajaran dalam mengembangkan pemahaman konsep IPA di $\mathrm{SD} ; 2)$ guru hendaknya melakukan variasi penggunaan model pembelajaran agar perbedaan karakteristik siswa dapat diperhatikan; 3) mengingat masih ada nilai pemahaman konsep IPA siswa yang belum memenuhi KKM, maka guru hendaknya lebih sering mengajak siswa untuk berlatih menjawab soal pemahaman konsep IPA; 4) untuk mengembangkan gaya kognitif siswa agar menjadi reflektif, maka guru dapat melatih siswa agar mandiri berpikir dengan cara menggunakan model-model pembelajaran yang dapat mengakomodasi gaya kognitif siswa agar sesuai dengan yang diharapkan; 5) apabila guru hendak menerapkan model POGIL, agar pembelajaran berlangsung efektif dan mendapatkan hasil yang maksimal, sebaiknya siswa dikelompokkan secara heterogen antara siswa impulsif dan siswa reflektif; 6) apabila peneliti lain hendak menerapkan model POGIL dan gaya kognitif untuk melihat pengaruhnya terhadap pemahaman konsep IPA, sebaiknya memilih jumlah sampel yang lebih banyak, dan melakukan penentuan gaya kognitif dengan cara yang tepat. Sehingga nantinya hasil yang diperoleh benar-benar mencerminkan kondisi sebenarnya.

\section{DAFTAR RUJUKAN}

Backhaus, Kristin dan Joshua P. Liff. 2007. "Cognitive Styles and Approaches to Studying in Management Education". Volume 31, Nomor 4 (hlm. 445-466). Tersedia pada http://e-resources.perp usnas.go.id:2057/docview/195713081/f ulltextPDF?A-ccountid $=25704 \quad($ diakses tanggal 15 November 2015)

Barthlow, Michele J. 2011. "The Effectiveness of Process-Oriented Guided Inquiry Learning to Reduce Alternative Conceptions in Secondary Chemistry". Disertasi Doktor Kepe -ndidikan Universitas Liberty. U.S.A.: ProQuest Dissertations Publishing.

Barthlow, Michele J. dan Scott B. Watson. 2011. "The Effectiveness of ProcessOriented Guided Inquiry Learning to Reduce Alternative Conceptions in Secondary Chemistry". Blackwell Publishing Ltd., Volume 114. Nomor 5 (hlm. 246 - 255).

Daraini, Rini. 2012. "Pengaruh Pembela -jaran Berbasis Multimedia dan Gaya Kognitif terhadap Kemampuan Pemecahan Masalah Matematika Siswa SMP Negeri Lubuk Pakam". Pascasarjana Unimed, Volume 5, Nomor 2 (hlm. 236 - 243). Tersedia pada http://digilib. unimed.ac.id/ public/UNI MED-Article-25771-9-RINI

\%20DARAINI.pdf (diakses tanggal 15 November 2015)

Hale, Dena dan Linda Greef Mullen. 2009. "Designing Process-Oriented GuidedInquiry Activities: A New Innovation for Marketing Classes". Volume 19, Nomor 1 (hlm. 73 - 80).

Hanson, David M. 2006. Instructor's Guide to Process-Oriented Guided-Inquiry Learning. Lisle, IL: Pacific Crest.

Muldrow, April Michelle. 2008. "Achieve -ment Motivation in African American College Students". Disertasi (tidak diterbitkan). Tersedia pada http://eresources.perpusnas.go.id: $20 \quad 57 / \mathrm{docv}$ 
iew/304413869/previewPDF?accountid= 25704 (diakses tanggal 24 November 2015)

Rasana, I Dewa Putu Raka. 2009. Laporan Subbatical Leave Model-model Pembelajaran. Singaraja: Undiksha.

Simonson, Shawn R. dan Susan E. Shadle. 2013. "Implementing Process Oriented Guided Inquiry Learning (POGIL) in Undergraduate Biomechanics: Lessons Learned by A Novice". Volume 14 (hlm. $56-63)$.
Sulastriningsih, Putu dan Kadek Suranata. 2013. "Pengaruh Model Process Oriented Guided Inquiry Learning Terhadap Kemampuan Pemahaman Konsep IPA siswa Kelas V SD Gugus IX Kecamatan Buleleng”. Undiksha, Volume 1. Tersedia pada http://ejournal .undiksha.ac.id/index.php/JJPGSD/ arti cle/view/820/693 (diakses tanggal 9 Januari 2016)

Undang-Undang Republik Indonesia No. 20 Tahun 2003 tentang Sistem Pendidikan Nasional, tersedia pada http://ke menag.go.id/file/dokumen/UU2003.pdf (diakses tanggal 6 Januari 2016) 